\title{
Do Narcissists and High Machs More Empowered? Assessing the Relationship between Machiavellianism and Narcissism, and Psychological Empowerment
}

\author{
Amir M. T. Yazdi ${ }^{1} \&$ Norizah Mohd Mustamil ${ }^{1}$ \\ ${ }^{1}$ Department of Business Strategy and Policy, Faculty of Business and Accountancy, University of Malaya, \\ Kuala Lumpur, Malaysia \\ Correspondence: Norizah Mohd Mustamil, Department of Business Strategy and Policy, Faculty of Business and \\ Accountancy, University of Malaya, 50603, Kuala Lumpur, Malaysia. Tel: 60-37-967-3949. E-mail: \\ norizahmm@um.edu.my
}

Received: March 13, 2014

Accepted: May 4, 2014

Online Published: June 22, 2014

doi:10.5539/ijbm.v9n7p78

URL: http://dx.doi.org/10.5539/ijbm.v9n7p78

\begin{abstract}
Given the abundant individual and organizational outcomes of empowerment, identifying employees who can be more empowered than others can be quite beneficial for organizations. The goal of this study was to test the relationship between both Narcissism and Machiavellianism, and psychological empowerment. To do so, 223 front-line service workers working in different industries in tertiary sector in Iran were selected and data was collected using self-reported questionnaire. The results indicated that by affecting three cognitions of impact, self-determination, and competence/self-efficacy, Narcissism positively relates to psychological empowerment. Despite the significant positive relationship between Machiavellianism and the cognition of impact, unexpectedly, no significant link between Machiavellianism and overall measure of psychological empowerment was found. This was attributed to significant negative relationship between Machiavellianism and empowerment's dimension of meaning. Identifying individual differences, such as Narcissism, which are positively related to empowerment can be tremendously useful during human resource selection. In other words, the result suggests that employing individuals with some degree of healthy Narcissism can be quite fruitful for the organizations especially those operating in the service sector.
\end{abstract}

Keywords: psychological empowerment, narcissism, machiavellianism, service workers, personality

\section{Introduction}

Understanding individuals' characteristics, related to empowerment can go a long way in benefiting organizations by helping them in staffing procedures to identify and select individuals who can experience higher level of empowerment. Having more empowered employees has tremendous benefits for both organizations and individuals. In addition, for the service organizations, in which there is a high involvement between service employees and customer, having more empowered employees can significantly increases customers satisfaction (Bowen \& Lawler, 1992; Melhem, 2004).In spite of the importance of identifying these individuals' characteristics, only handful of studies addressed this void in order to expand our understanding to answer this question that who is more empowered.

We are not overstating if we present empowerment as alchemy, since it transforms individuals in theorganization to super-employees. In their meta-analysis, Seibert and colleagues (2011) identified significant attitude and behavior-related outcomes of empowerment, found in various empowerment-related studies. They reported that empowered employees are more satisfied with their jobs (Number of studies 53; Mean corrected correlation, highly committed to their organizations, less susceptible to strain, and less likely to quit their jobs. On the other hand, empowered employees are more creative, have higher task performance, and higher organizational citizenship behaviors.

Given the importance of empowered employees to the organizations, it is not surprising that the vast number of studies were conducted to identify practices, policies, and structures that foster empowerment. Empowerment conceptualization significantly changed over time. Until two decades ago, the notion of empowerment was conceptualized by empowering practices and structures (i.e. Social structural empowerment; Eylon\& Bamberger, 
2000). Studies of empowerment in social-structural boundaries mostly conducted under the terms alienation, job enrichment (Spreitzer, 1996), high performance work system, and high involvement work practices (Spreitzer, 2007). Kanter's (1977) famous study, men and women of the corporation, can be considered as the foundation of structural empowerment. She contended that the feeling of power depends on the degree to which employees have access to two structures of power (i.e. information, resources, and support) and opportunity.

By conceptualizing empowerment as a motivational construct, Cogner\&Kanungo (1988), and Thomas \&Velthouse, (1990) began the new approach of empowerment (i.e., psychological empowerment) that focuses mostly on individual's' perception toward empowering practices, policies, and structures rather than those practices per se. Spreitzer (1995) conceptualized empowerment as a psychological state that manifests in four cognitions of meaning, self-determination, competence/self-efficacy, and impact. The dimension of meaning, which extracted from Hackman \& Oldham's (1975) psychological state of meaningfulness, denotes the degree to which employees' jobs are personally important to them. Rooted in Hackman \& Oldham's (1975) job characteristic of autonomy and psychological state of experienced responsibility, cognition of self-determination refers to employees' sense of having freedom in determining how to do their jobs. Identical to Bandura's (1977) self-efficacy, competence refers to the degree to which employees believe they have capability to carry out their tasks successfully. Finally dimension of impact denotes the degree to which employees believe they have significant influence on their organization as a whole.

\subsection{Individuals' Characteristics as Antecedents of Empowerment}

Thomas and Velthouse (1990) contended that the feeling of empowerment is the result of individuals' task assessments (i.e., meaningfulness, impact, competence and choice) and therefore it is quite subjective to individuals' interpretation. On the other hand, Spreitzer (1995) posited that empowerment is the outcome of ongoing employees' perception about themselves in relation to the work environment. Thus, individuals' differences, including differences in demographics and personality traits, matter for empowerment since they significantly influence individuals' interpretation and perception. Based on this, some studies assessed individuals' characteristics as antecedents of psychological empowerment. In term of demographics at individual level of analysis, Spreitzer (1995) reported significant association between tenure, education, and greater rank and empowerment (Spreitzer, 2007). In addition, Seibert et al. (2011) reported significant relationship between tenure, job level, and age and empowerment. At the team-level of analysis, racial diversity among team members and also between team-members and their leader were found to be negatively associated with the empowerment (Kirkman et al., 2004).

Spreitzer (1995) for the first time proposed the link between some personality traits (i.e. locus of control and self-esteem) and psychological empowerment. Between these two, only self-esteem showed significant relationship with empowerment. In addition, Individuals with more positive core self-evaluation were found to be more empowered (Laschinger et al., 2009; Seibert et al., 2011). Laschinger and colleagues (2007) depicted that core self-evaluation in nurse managers is positively associated with workplace empowerment. According to Avey et al. (2008), Psychological capital (i.e., individuals' positive psychological state of development conceptualized with four dimensions of self-efficacy, optimism, hope, and resiliency (Luthans et al., 2007) significantly predicts individuals' feeling of empowerment. Furthermore, Sutherland and colleagues (2007) adopted Cloete et al. (2002) Employee Empowerment Questionnaire (EEQ, i.e., combination of psychological empowerment and empowerment climate) for measuring the notion of empowerment and found significant relationship between conscientiousness and empowerment. In their dimensional analysis, Hon \&Rensvold (2006) tested the relationship between need for achievement and need for power, and each of psychological empowerment's dimensions. Need for achievement showed positive significant association with all four dimensions of empowerment (i.e. meaning, competence/self-efficacy, impact, and self-determination), whereas need for power was only related to empowerment's dimension of competence/self-efficacy. It seems that there is a strong connection between both Narcissism and Machiavellianism, and empowerment since these personality traits are associated with high perceived control and self-efficacy (i.e.,two foundations of empowerment).

\subsection{Machiavellianism and Psychological Empowerment}

Machiavellianism is originated from the handbook "The Prince", written by Niccole Machiavelli, who was Medici family's advisor in Florence in $16^{\text {th }}$ century. Machiavelli believed that any effective tactics, regardless of its morality, is acceptable. In 1970, Christie \&Geis, who observed similarity between Machiavelli's political tactics and some people's social behaviors, conceptualized Machiavellianism in their famous study, Studies of Machiavellianism(Jones, et al., 2009). Christie \&Geis (1970) described high Machs as cunning, dishonest and unethical individuals (Hodson et al., 2009) and categorized high Machs' characteristics into three main themes: 
using deceitful and manipulative strategies in dealing with others, perceiving other as lazy and untrustworthy, and not believing in any conventional morality (Shepperd\&Socherman, 1997; O'Boyle et al., 2012).

By reviewing the studies related to Machiavellianism within the organizational boundaries, Dahlinget al. (2009)identified some important organizational implications of Machiavellianism (i.e., leadership, economic opportunism, defection, theft, influence tactics, job satisfaction, occupational choice, and helping behaviors).Research on Machiavellianism showed that high Machs have propensity to engage in some unproductive work behaviors, comprising economic opportunism (Sakalaki et al., 2007; i.e., high Machs have inclination to maximize their own benefits and interests instead of trusting and cooperating with partners), defection(Wilson, Near, \& Miller, 1996; i.e. within a group, high Machs tend to conceal their true nature while make the most of their exploitive skills), and theft (Harrell et al., 1976). Machiavellianism was also found to be negatively related to job satisfaction(Gemmill et al., 1972) and helping behavior(Wolfson, 1981). According to Pandey and Rastogi (1979) and Dingler-Duhon and Brown, (1987), high Machstend to use some specific influence tactics (e.g., ingratiation, intimidation, and self-disclosure) to achieve their goals. The studies related to Machiavellian leaders' behavior was found to be a bit contradicting. For instance, Drory and Gluskinos (1980) maintained that high Mach leaders tend to be more flexible in dealing with both structured and unstructured tasks, although they show little consideration for interpersonal matters. On the other hand, by showing the positive rating of charisma and performance for the past high Mach US presidents, Deluga (2001) provided evidence that high Mach leaders may also have the capability to give appearance of caring for others

High Machs are hypercompetitive individuals, who are apt to overemphasize on the competence value (Jones \& Paulhus, 2009), overestimate their actual performance, and over-place themselves in caparison with others(Moore et al., 2008). In addition, Machiavellianism was found to be positively related to self-efficacy (Bodey \& Grace, 2004; Boozer et al., 2005). Thereby, employees with higher Machiavellianism are more likely to believe they have necessary capabilities to carry out their tasks. On the other hand, psychological empowerment is strongly rooted in Bandura's (1977) self-efficacy. Cogner \& Kanungo, (1988) described empowerment as enhanced feeling of self-efficacy. Furtheremore, as it has been mentioned earlier, Spreitzer (1995) idenftified competence/self-efficacy as one of four cognitions of psychological empowerment.

According to Dahling and collegues (2009), high Machs have desire to dominate inter-personal situations and to be in control. Other studies (e.g., Jones \& Paulhus, 2009; Bodey \& Grace, 2004) also found positive association between Machiavellianism and the perception of control. Perception of control and psychological empowerment are considered to be almost synonymous(Cogner et al., 1988). Psychological empowerment was defined as set of cognitions or psychological states that make employees feel they are in control over their work (Spreitzer, 2007; Maynard et al., 2012). Thomas \& Velthouse (1990, p7) contended that employees percieve themselves in control of the environment, only when they belive that their behaviors have significant impact (i.e., higher empowerment's dimension of impact), and they can carry out their tasks competently (i.e. higher empowerment's dimension of competence/self-efficacy). In other words, higher perception of control is the result of enhanced feeling of impact and competence. In addition, Shepperd \& Socherman (1997) held that individuals, who score higher in Machiavellianism, are apt to perceive themselves as dominant and domineering individuals or as "king of the jungle". Thus, it is expected that high Machs believe they have significant impact on determining the work's outcomes.

Hackman et al. (1975) defined autonomy (i.e. similar to empowerment dimension of self-determination) as objective personal control over the work. Thereby, due to their high level of percieved control, high Machs are expected to have higher self-determination. Therefore based on abovementioned evidences we hypothesized that:

H1: Machiavellianism positively relates to psychological empowerment.

\subsection{Narcissism and Psychological Empowerment}

Throughout the literature, Narcissism has been treated both as a personality and as a clinical disorder (Campbell et al., 2004). Narcissism emerges in three different attitudes and behaviors of self, interpersonal relationship, and self-regulatory strategy. In other words, Narcissists believe they are more entitled, intelligent, unique, and special (i.e., Narcissistic self). Moreover, Narcissists usually are incapable of establishing intimate and deep relationships, and their relationships merely can range from appealing to abusive types (i.e., interpersonal relationship). Finally, Individuals with high Narcissism tend to take advantage of any opportunities to be respected, admired, and in center of attention (Campbell et al., 2011).

According to the Agency model(Campbell et al., 2006; Campbell \& Foster, 2007),individuals high on the narcissism tend to use agentic means to satisfy their core self-motives comprising power, entitlement, grandiosity, and self-esteem.Building upon the agency model and Paulhus and John's (1998) self-perception bias model (i.e. 
a model stating that self-favoring tendencies can be divided into two separate dimensions of egoistic and moralistic bias), Gebauer and colleagues (2012) introduced a new type of narcissism (i.e. communal narcissism). In contrast to agentic narcissists, who are apt to exaggerate their seeming virtues via agentic means (e.g. by braggingabout their competence, intelligence, extraversion, and attractiveness) and have a "superhero" quality, communal narcissists use communal means (e.g. by exaggerating about their relatedness, agreeableness, and warmth) to feed their core self-motives, and thereby they can be described as "saint" types (Gebauer et al., 2012). Testing on 304 twin-pairs, Luo et al. (2014) found that both agentic and communal narcissism are moderately heritable. They maintained that the same genes account for one third of the heritability of both communal and agentic narcissism, whereas the other two third of heritability is accounted for by separate genetic factors.

It is important to note that narcissism, similar to other personality traits, is a continuous variable, therefore individuals can be regarded as more or less Narcissist rather than being a Narcissist or not. Even a little more of narcissism can significantly influences individuals' attitudes and behaviors (O'Boyle et al., 2012).Individuals with higher degree of Narcissism, have tendency to overestimate their skills and abilities which reflects in their feeling of overconfidence (Campbell et al., 2004).

Narcissism is mainly characterized by the high tendency to think well about oneself (Barry et al., 2003). On the other hand, perception of self-worth seems to matter for empowerment since both self-esteem (Spreitzer, 1995) and core self-evaluation (Laschinger et al., 2007), two personality traits that represent individuals' perception of self-worth, were identified as significant antecedents of empowerment. In addition, individuals, who see their "selves" in more positive light, are apt to believe that they are more competent at performing their tasks in workplace(Bandura, 1977). Beside the self-efficacy, perceived impact was also found to be higher in Narcissists. By evaluating MBA students' perceived contribution to a group discussion, John \& Robins (1994) found that individuals who score higher in Narcissism perceived themselves as more impactful compare to others. Thus,

H2: Narcissism positively relates to psychological empowerment.

\section{Methods}

\subsection{Sample}

Sample consisted of 223 service workers selected from diverse industries of service sector in Iran (24 companies within 9 different industries). Initially, 270 questionnaires were collected (with response rate of 83 percent), however 43 were discarded from the sample because of having missing variable, central tendency, or other problems. Service workers were largely men $(59.2 \%)$, between 29 and 35 years old (35\%), had bachelor degree (51.1\%), and had over fifteen years of experience (29.1\%; See table 1). Out of 264 collected questionnaires, 41 were discarded during data cleaning process due to some problems (e.g. missing variables, central tendency bias).

\subsection{Measures}

Narcissism was measured using unidimensional measure $(\alpha=.795)$ developed by Ames et al. (2006). Dahling et al.'s (2009) four dimensions of amoral manipulation $(\alpha=.793)$, desire for status $(\alpha=.831)$, desire for control $(\alpha=.766)$ and distrust of others $(\alpha=.866)$ were adopted for measuring Machiavellianism. Finally psychological empowerment was measured using Spreitzer's (1995) four cognitions of meaning ( $\alpha=.757$ ), impact $(\alpha=.810)$, competence $(\alpha=.712)$ and self-determination $(\alpha=.703)$. All measures were self-reported and were in five-point likert scale format ( $1=$ strongly disagree to $5=$ strongly agree). In order to translate measurement instrument from English to Farsi, back-to-back translation was conducted. At first, two professional translators translated questionnaire from English to Farsi without knowing about each other. When two forward translations were completed, translators discussed with each other and came up with one finalized questionnaire. In the next step, two other professional translators translated the questionnaire back to English while they were blind to the original version. Once two back translations were completed, translators discussed and came up with one questionnaire. After comparing with original questionnaire and making revision, two translators finalized Farsi version of questionnaire. 
Table 1. Demographic characteristics of the sample

\begin{tabular}{llll}
\hline Demographic Variables & levels & Frequency & $\%$ \\
\hline Age & $18-28$ & 52 & 23.3 \\
& $29-35$ & 78 & 35 \\
& $36-45$ & 69 & 30.9 \\
& Above 45 & 24 & 10.8 \\
\hline Gender & Male & 133 & 59.2 \\
& Female & 90 & 39.9 \\
\hline Education & High-school diploma & 86 & 38.6 \\
& Bachelor & 114 & 51.1 \\
& Master or Ph.D & 23 & 10.3 \\
\hline Work Eperience & Less than 5 & 55 & 24.7 \\
& $5-10$ years & 62 & 27.8 \\
& $11-15$ years & 41 & 18.4 \\
& Over 15 years & 65 & 29.1 \\
\hline
\end{tabular}

Table 2. Univariate analysis and Pearson correlation

\begin{tabular}{|c|c|c|c|c|c|c|c|c|c|c|c|c|c|c|}
\hline & $\alpha$ & Mean & S.D & 1 & 2 & 3 & 4 & 5 & 6 & 7 & 8 & 9 & 10 & 11 \\
\hline 1. Narcissism & .795 & 3.20 & .56 & 1 & & & & & & & & & & \\
\hline 2. Mach-Amorality & .793 & 1.20 & .61 & $.228^{* *}$ & 1 & & & & & & & & & \\
\hline 3. Mach-Control & .766 & 2.88 & .73 & $.430 * *$ & $.302 * *$ & 1 & & & & & & & & \\
\hline 4. Mach-Status & .831 & 3.68 & .83 & $.372 * *$ & $.162 *$ & $.306^{* *}$ & 1 & & & & & & & \\
\hline 5. Mach-Distrust & .865 & 3.11 & .82 & $.152^{*}$ & $.320 * *$ & $.245^{* *}$ & $.197 * *$ & 1 & & & & & & \\
\hline 6. Machiavellianism & -- & 2.91 & .50 & $.446 * *$ & $.620 * *$ & $.688 * *$ & $.659^{* *}$ & $.683 * *$ & 1 & & & & & \\
\hline 7. PE- Meaning & .757 & 4.00 & .63 & -.114 & $-.317^{* *}$ & $-.141^{*}$ & .101 & -.110 & $-.154 *$ & 1 & & & & \\
\hline 8.PE-Competence & .712 & 4.03 & .57 & $.210^{* *}$ & $-.260^{* *}$ & .004 & $.196^{* *}$ & -.066 & -.025 & $.381 * *$ & 1 & & & \\
\hline 9. PE- Self-Determination & .703 & 3.16 & .73 & $.169^{*}$ & -.091 & -.016 & .095 & .085 & .041 & $.183^{* *}$ & $.242 * *$ & 1 & & \\
\hline 10.. PE- Impact & .810 & 3.22 & .78 & $.215^{* *}$ & .042 & $.176^{* *}$ & .118 & .052 & $.148^{*}$ & $.214^{* *}$ & $.317 * *$ & $.370^{* *}$ & 1 & \\
\hline 11.Psychological & -- & 3.61 & .46 & $.184 * *$ & $-.205^{* *}$ & .021 & $.182^{* *}$ & -.002 & .019 & $.619 * *$ & $.667 * *$ & $.688 * *$ & $.740 * *$ & 1 \\
\hline Empowerment & & & & & & & & & & & & & & \\
\hline
\end{tabular}

All variables were measured on five-point likert scale.

Note. ${ }^{*} \mathrm{P}<0.05, * * \mathrm{P}<0.01$.

Table 3. The result of multiple regression analysis

\begin{tabular}{lll}
\hline & $\begin{array}{l}\text { DV: } \\
\text { Empowerment a }\end{array}$ & PIF \\
\hline Control Variables & & 1.046 \\
Gender & -.025 & 3.282 \\
Age & -.142 & 3.284 \\
Work Experience & -.005 & 1.097 \\
Education & -.051 & \\
\hline Predictor Variables & & 1.276 \\
\hline Machiavellianism & -.099 & 1.287 \\
Narcissism & $.212^{* *}$ & \\
R2 &. .055 & \\
Adjusted R2 & .029 & \\
$\Delta$ R2 & .035 & \\
F & 2.094 \\
\hline
\end{tabular}

Astandardized regression coefficient reported;

Note. ${ }^{*} \mathrm{p}<0.05$ one-tailed test; ${ }^{* *} \mathrm{p}<0.01$ one-tailed test; ${ }^{* * *} \mathrm{P}<0.001$ one-tailed test. 


\section{Results}

Skeweness and kurtosis for all measures were between 1 and -1 , therefore data was normally distributed (see Table 2). Second-order factor analysis indicated good fit between data and hypothesized model (AGFI= .814, $\mathrm{CFI}=.928, \mathrm{PCFI}=.851, \mathrm{RMSEA}=.041, \mathrm{CMIN} / \mathrm{DF}=1.365)$. For testing both hypotheses, hierarchical multiple regression was employed while controlling for demographic variables (i.e., gender, age, education and work experience). According to the expectation, narcissism was significantly related to psychological empowerment $(\beta=.212, \mathrm{P}<0.01)$. Narcissism showed positive significant association with three empowerment's dimensions of competence, self-determination, and impact (see Table 4).

Table 4. The result of dimensional multiple regression analysis

\begin{tabular}{|c|c|c|c|c|c|c|c|c|}
\hline & \multicolumn{2}{|c|}{ Meaning } & \multicolumn{2}{|c|}{ Competence } & \multicolumn{2}{|c|}{ Self-determination } & \multicolumn{2}{|c|}{ Impact } \\
\hline & $\beta$ Model 1a & $\beta$ Model 2 & $\beta$ Model 1 & $\beta$ Model 2 & $\beta$ Model 1 & $\beta$ Model 2 & $\beta$ Model 1 & $\beta$ Model 2 \\
\hline \multicolumn{9}{|l|}{ Control Variables } \\
\hline Gender & -.043 & -.083 & -.035 & -.076 & .123 & .092 & -.114 & -.111 \\
\hline Age & -.070 & -.025 & $-.256^{*}$ & -.150 & .000 & .074 & -.094 & -.051 \\
\hline Work experience & -.136 & -.207 & .058 & -.024 & .024 & -.035 & .032 & .027 \\
\hline Education & $-.158^{*}$ & $-.143 *$ & .056 & .054 & -.048 & -.042 & .009 & -.007 \\
\hline \multicolumn{9}{|l|}{ Predictors } \\
\hline Narcissism & & -.081 & & $.222 * *$ & & $.215 * *$ & & $.169^{*}$ \\
\hline Amorality & & $-.341 * * *$ & & $-.339 * * *$ & & $-.147 *$ & & -.047 \\
\hline Control & & -.062 & & -.072 & & -.098 & & .095 \\
\hline Status & & $.150^{*}$ & & $.159 *$ & & .057 & & .032 \\
\hline Distrust & & -.003 & & .015 & & .099 & & .015 \\
\hline Model F & $2.805^{*}$ & $5.644 * * *$ & $2.833^{*}$ & $6.070 * * *$ & .880 & $1.973^{*}$ & .823 & 1.708 \\
\hline R2 & .049 & .194 & .050 & .206 & .016 & .078 & .015 & .068 \\
\hline Adjusted R2 & .032 & .160 & .032 & .172 & -.002 & .038 & -.003 & .028 \\
\hline$\Delta \mathrm{R} 2$ & & .145 & & .156 & & .062 & & .053 \\
\hline
\end{tabular}

Astandardized regression coefficient reported;

Note. ${ }^{*} \mathrm{P}<.05 ; * * \mathrm{P}<.01 ; * * * \mathrm{P}<.001$.

Contrary to expectation, Machiavellianism was not found to be significantly related to psychological empowerment (see table 3). Machiavellianism showed significant relationship with empowerment's dimensions of meaning $(\beta=-.196, \mathrm{P}<0.01)$ and impact $(\beta=.142, \mathrm{P}<0.05)$. Machiavellianism's dimension of desire for status depicted positive association with empowerment's dimensions of meaning and competence, whereas amoral manipulation showed negative significant relationship with meaning, competence, and self-determination (see table 4). In contrast to Spreitzer's (1995) finding, our result didn't show significant relationship between any of demographic variables and psychological empowerment.

\section{Discussion and Limitation}

The findings supported the second hypothesis and identified narcissism as an antecedent of psychological empowerment but no evidence was found to support the link between Machiavellianism and psychological empowerment. As we expected Machiavellianism was associated with dimension of impact. High Mach's tendency to manipulate others (i.e., amoral manipulation dimension) was found to be the main cause for the negative association between Machiavellianism and perception of meaning. Because of their propensity to manipulate others, high Machs are more likely to be apathetic toward their workplace and they are less likely to find their work meaningful.

Narcissism was found to be related to all psychological empowerment's dimensions except for meaning. Significant relationship between self-esteem (Spreitzer, 1995), core self-evaluation (Laschinger et al., 2009), and 
narcissism and psychological empowerment testify that perception of self-worth do matter for empowerment. The result suggests that existing narcissism to some extent can have positive outcomes at organizational level. Employing individuals with higher perception of self-worth helps organization to have more empowered employees in future.

Naturally, this study has several methodological limitations. First, drawing sample from limited industries of tertiary sector (9 industries) and also usage of non-probability sampling method might have introduced some bias into analysis. In addition, since the measures were self-reported, therefore the result might have affected by common method variance bias.

\section{References}

Avey, J. B., Hughes, L. W., Norman, S. M., \& Luthans, K. W. (2008).Using positivity, transformational leadership and empowerment to combat employee negativity.Leadership \& Organization Development Journal, 110-126. http://dx.doi.org/10.1108/01437730810852470

Bandura, A. (1977). Self-efficacy: Toward a unifying theory of behavioral change. Psychological Review, 191-215. http://dx.doi.org/10.1037/0033-295X.84.2.191

Barry, C. T., Frick, P. J., \& Killian, A. L. (2003). The Relation of Narcissism and Self-Esteem to Conduct Problems in Children: A Preliminary Investigation. Journal of Clinical Child and Adolescent Psychology, 139-152. http://dx.doi.org/10.1002/ab.20198

Bodey, K., \& Grace, D. (2004). Examining Self-Monitoring, Perceived Control, Self-Efficacy and Machiavellianism in the Context of Complaint Behaviour. Marketing Accountabilities and Responsibilities, Proceedings of Australian \& New Zealand Marketing Academy. Australian \& New Zealand Marketing Academy.

Boozer, R. W., Forte, M., \& Harris, J. R. (2005). Psychological Type, Machiavellianism, and Perceived Self-efficacy at Playing Office Politics. Journal of Psychological Type, 1-9.

Bowen, D. E., \& Lawler, E. (1992). The empowerment of service workers: What, why, how and when? Sloan Management Review, 31-39.

Campbell, W. K., \& Foster, J. D. (2007). The narcissistic self: Background, an extended agency model, and ongoing controversies. In C. S. Spencer (Ed.), The self (pp. 115-138). New York: Psychology Press.

Campbell, W. K., Brunell, A. B., \& Finkel, E. J. (2006). Narcissism, interpersonal selfregulation, and romantic relationships: An Agency Model approach. In E. J. Finkel \& K. D. Vohs (Eds.), Self and relationships: Connecting intrapersonal and interpersonal processes (pp. 297-316). New York: Guilford Press.

Campbell, W. K., Goodie, A. S., \& Foster, J. D. (2004).Narcissism, Confidence, and Risk Attitude.Journal of Behavioral Decision Making, 297-311.http://dx.doi.org/10.1002/bdm.475

Campbell, W. K., Hoffman, B. J., Campbell, S. M., \& Marchisio, G. (2011).Narcissism in organizational contexts.Human Resource Management Review, 268-284. http://dx.doi.org/ 10.1016/j.hrmr.2010.10.007

Christie, R., \& Geis, F. L. (1970). Studies in Machiavellianism. New York: Academic Press.

Cloete, V. J., Crous, F., \& Schepers, J. M. (2002).The construction and evaluation of a scale of employee empowerment. Journal of Industrial Psychology, 31-36. http://dx.doi.org/10.4102/sajip.v28i2.55

Cogner, J. A., \& Kanungo, R. N. (1988). The Empowerment Process: Integrating Theory and Practice. Academy ol Management Review, 471-482. http://dx.doi.org/ 10.5465/AMR.1988.4306983

Dahling, J. J., Whitaker, B. G., \& Levy, P. E. (2009).The Development and Validation of a New Machiavellianism Scale. Journal of Management, 219-257. http://dx.doi.org/10.1177/0149206308318618

Deluga, R. J. (2001). American presidential Machiavellianism: Implications for charismatic leadership and rated performance. Leadership Quarterly, 339-363. http://dx.doi.org/10.1016/S1048-9843(01)00082-0

Dingler-Duhon, M., \& Brown, B. B. (1987). Self-disclosure as an influence strategy: Effects of machiavellianism, androgyny, and sex. Sex Roles, 109-123. http://dx.doi.org/10.1007/BF00289643

Drory, A., \& Gluskinos, U. M. (1980).Machiavellianism and Leadership.Journal of Applied Psychology, 81-86. http://dx.doi.org/10.1037/0021-9010.65.1.81

Eylon, D., \& Bamberger, P. (2000).Empowerment Cognitions and Empowerment Acts.Group and Organization Management, 354-372. http://dx.doi.org/10.1177/1059601100254003 
Gebauer, J. E., Sedikides, C., Verplanken, B., \& Maio, G. R. (2012).Communal Narcissism.Journal of Personality \& Social Psychology, 854-878. http://dx.doi.org/10.1037/a0029629

Gemmill, G. R., \& Heisler, W. J. (1972). Machiavellianism as a Factor in Managerial Job Strain, Job Satisfaction, and Upward Mobility. Academy of Management Journal, 51-62. http://dx.doi.org/10.2307/254800

Hackman, J. R., \& Oldham, G. R. (1975). Development of the Job Diagnostic Survey.Journal of Applied Psychology, 159-170. http://dx.doi.org/10.1037/h0076546

Harrell, W. A., \& Hartnagel, T. (1976). The impact of Machiavellianism and the trustfulness of the victim on laboratory theft. Sociometrv, 157-165.

Hodson, G., Hogg, S. M., \& MacInnis, C. C. (2009). The role of "dark personalities" (narcissism, Machiavellianism, psychopathy), Big Five personality factors, and ideology in explaining prejudice. Journal of Research in Personality, 686-690.http://dx.doi.org/10.1016/j.jrp.2009.02.005

Hon, A. H., \& Rensvold, R. B. (2006). An interactional perspective on perceived empowerment: the role of personal needs and task context. International Journal of Human Resource Management, 959-982. http://dx.doi.org/10.1080/09585190600641271

John, O. P., \& Robins, R. W. (1994). Accuracy and bias in self-perception: Individual differences in self-enhancement and the role of narcissism. Journal of Personality \& Social Psychology, 206-219.http://dx.doi.org/10.1037/0022-3514.66.1.206

Jones, D., \&Paulhus, D. L. (2009).Machiavellianism. In M. R. Leary, \& R. H. Hoyle (Eds.), Individual Differences in Social Behavior (pp. 93-108). New York: Guilford.

Kanter, R. M. (1977). Men and women of the corporation. New York: Basic Books.

Kirkman, B. L., Tesluk, P. E., \& Rosen, B. (2004). The Impact of Demographic Heterogeneity and Team Leader Team Member Demographic Fit on Team Empowerment and Effectiveness.Group \& Organization Management, 334-368. http://dx.doi.org/10.1177/1059601103257412

Laschinger, H. K., Finegan, J., \&Wilk, P. (2009). Context Matters: The Impact of Unit Leadership and Empowerment on Nurses' Organizational Commitment. The journal of Nursing Administration, 228-235. http://dx.doi.org/10.1097/NNA.0b013e3181a23d2b

Laschinger, H. K., Purdy, N., \& Almost, J. (2007). The Impact of Leader-Member Exchange Quality, Empowerment, and Core Self-evaluation on Nurse Manager's Job Satisfaction. Journal of Nursing Administration, 221-229. http://dx.doi.org/10.1097/01.NNA.0000269746.63007.08

Luo, Y. L., Cai, H., Sedikides, C., \& Song, H. (2014). Distinguishing communal narcissism from agentic narcissism: A behavior genetics analysis on the agency-communion model of narcissism. Journal of Research in Personality, 52-58. http://dx.doi.org/10.1016/j.jrp.2014.01.001

Luthans, F., Youssef, C. M., \& Avolio, B. J. (2007). Psychological Capital: Developing the Human Competitive Edge. Oxford: Oxford University Press. http://dx.doi.org/10.1093/acprof:oso/9780195187526.001.0001

Maynard, M. T., Gilson, L. L., \& Mathieu, J. E. (2012). Empowerment—Fad or Fab?A Multilevel Review of the Past Two Decades of Research. Journal of Management, 1231-1281. http://dx.doi.org/10.1177/0149206312438773

Melhem, Y. (2004). The antecedents of customer-contact employees' empowerment. Employee Relations, 72-93. http://dx.doi.org/ 10.1108/01425450410506913

Moore, D., \& Healy, P. J. (2008). The Trouble with Overconfidence. Psychological Review, 502-517. http://dx.doi.org/10.1037/0033-295X.115.2.502

O’Boyle, J. E., Forsyth, D. R., Banks, G. C., \& McDaniel, M. A. (2012). A Meta-Analysis of the Dark Triad and Work Behavior: A Social Exchange Perspective. Journal of Applied Psychology, 557-579. http://dx.doi.org/10.1037/a0025679

Pandey, J., \& Rastogi, R. (1979). Machiavellianism and ingratiation. Journal of Social Psychology, 221-225. http://dx.doi.org/10.1080/00224545.1979.9711635

Paulhus, D. L., \& John, O. P. (1998). Egoistic and Moralistic Biases in Self-Perception: The Interplay of Self-Deceptive Styles with Basic Traits and Motives. Journal of Personality, 1025-1060. http://dx.doi.org/10.1111/1467-6494.00041

Sakalaki, M., Richardson, C., \& Thépaut, Y. (2007). Machiavellianism and Economic Opportunism. Journal of 
Applied Social Psychology, 1181-1190. http://dx.doi.org/10.1111/j.1559-1816.2007.00208.x

Seibert, S. E., Wang, G., \& Courtright, S. H. (2011). Antecedents and Consequences of Psychological and Team Empowerment in Organizations: A Meta-Analytic Review. Journal of Applied Psychology, 981-1003. http://dx.doi.org/10.1037/a0022676

Shepperd, J. A., \& Socherman, R. E. (1997). On the Manipulative Behavior of Low Machiavellians: Feigning Incompetence to "Sandbag" an Opponent. Journal of Personality and Social Psychology, 1448-1459. http://dx.doi.org/10.1037/0022-3514.72.6.1448

Spreitzer, G. (2007). Taking Stock: A review of more than twenty years of research on empowerment at work. The Handbook of Organizational Behavior. Sage Publication. http://dx.doi.org/10.4135/9781849200448

Spreitzer, G. M. (1995). Psychological Empowerment in Workplace: Dimensions, Measurment and Validation. Academy of Management Journal, 1442-1465. http://dx.doi.org/10.2307/256865

Spreitzer, G. M. (1996). Social Structural characteristics of Psychologycal Empowerment. Academy of Management Journal, 483-504. http://dx.doi.org/10.2307/256789

Sutherland, R., Bruin, G. P., \& Crous, F. (2007). The Relation between Conscientiousness, Empowerment and Performance. Journal of Human Resource Management, 60-67. http://dx.doi.org/10.4102/sajhrm.v5i2.

Thomas, K. W., \& Velthouse, B. A. (1990). Cognitive Elements of Empowerment: An "Interpretive" Model of Intrinsic Task Motivation. Academy of Manasrement Review, 666-681. http://dx.doi.org/10.5465/AMR.1990.4310926

Wilson, D. S., Near, D., \& Miller, R. R. (1996). Machiavellianism: A synthesis of the evolutionary and psychological literatures. Psychological Bulletin, 285-299. http://dx.doi.org/10.1037/0033-2909.119.2.285

Wolfson, S. L. (1981). Effects of Machiavellianism and communication on helping behaviour during an $\begin{array}{llll}\text { emergency. British Journal of } & \text { 328-332. }\end{array}$ http://dx.doi.org/10.1111/j.2044-8309.1981.tb00531.x

\section{Copyrights}

Copyright for this articleis retained by the author(s), with first publication rights granted to the journal.

This is an open-access article distributed under the terms and conditions of the CreativeCommons Attribution license (http://creativecommons.org/licenses/by/3.0/). 